\title{
In Vitro Evaluation of Fungicides, Plant Extracts and Biocontrol Agents against Brown Leaf Spot of Paddy
}

\author{
C. Channakeshava* and N.S. Pankaja \\ Department of Plant Pathology, College of Agriculture, V.C. Farm, Mandya, India \\ *Corresponding author
}

\begin{tabular}{|c|}
\hline Keywords \\
\hline $\begin{array}{l}\text { Fungicides, Plant } \\
\text { extracts, Biocontrol } \\
\text { agents, Mycelial growth } \\
\text { inhibition, Brown leaf } \\
\text { spot }\end{array}$ \\
\hline Article Info \\
\hline $\begin{array}{l}\text { Accepted: } \\
04 \text { April } 2018 \\
\text { Available Online: } \\
10 \text { May } 2018\end{array}$ \\
\hline
\end{tabular}

\section{Introduction}

Brown leaf spot of rice causes considerable qualitative and quantitative losses in rice growing countries of Asia, America and Africa (Ou, 1985). In India, the disease is widespread and known to cause4.6-29.0\% losses in grain yield (Bedi and Gill, 1960). The pathogen has been found to cause stalk rot in addition to leaf spot and grain discolouration in non-scented high yielding varieties of rice in Haryana (Sunder et al., 2005). The earlier recommended fungicides namely mancozeb and zineb have been found to impart insufficient control of the disease (Sunder et al., 2010).Several plant derived products have been found inhibitory to mycelial growth and spore germination of the pathogen (Bisht and Khulbe, 1995; Amadioha, 2002; Kumar, 2006).

The antagonistic behavior of biocontrol agent like Trichoderma harzianum and other species in vitro resulted in the overgrowth of $B$. 
oryzae by $T$. harzianum. While, the antifungal metabolites of $T$. harzianum completely prevented the linear growth of the pathogen (Abdel-Fattah et al., 2007). Keeping this in view, the present study was undertaken to evaluate the efficacy of fungicides, botanicals and biocontrol agents against brown spot of rice under laboratory conditions.

\section{Materials and Methods}

In vitro experiments were conducted in the Department of Plant Pathology, College of Agriculture, V. C. Farm, Mandya during 2015-16.

\section{Collection of diseased specimen and isolation of pathogen}

The infected leaves showing typical brown leaf spot symptoms were collected from naturally infected paddy plants from the field in and around College of Agriculture, V. C. farm, Mandya, Karnataka. These leaves were properly packed in polythene covers and stored at $4{ }^{\circ} \mathrm{C}$ for further studies. The infected portions of the leaves were used for isolation of the pathogen on potato dextrose agar medium. The pure culture of the pathogen was obtained by 'Separate Locate Isolate technique'. This culture was used for further laboratory studies.

\section{In vitro evaluation of fungicides}

The efficacy of ten different fungicides were tested at 50,100, 150, 200, 250 ppm, concentrations against the pathogen. The fungicides tested are listed in Table 1. These fungicides were evaluated by "Poison Food Technique" as given by Grover and Moore (1962). Required quantity of individual fungicide was added to cooled potato dextrose agar so as to get the desired concentration of the fungicide. Later, $20 \mathrm{ml}$ of the poisoned medium was poured into Petri plates. Mycelial disc of $5 \mathrm{~mm}$ in diameter was placed at the centre of the agar plate. The medium without any fungicide served as control. Three replications were maintained for each concentration. Inoculated plates were incubated at $26 \pm 2{ }^{\circ} \mathrm{C}$ and colony diameter was measured till the mycelial growth covered the entire Petri plates at $24 \mathrm{hr}$ interval. The efficacy of the fungicides was expressed as per cent inhibition of mycelial growth, which was calculated by using the formula given by Vincent (1947).

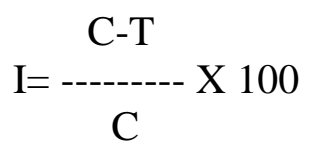

Where, $\mathrm{I}=$ per cent inhibition, $\mathrm{C}=$ growth in control, $\mathrm{T}=$ growth in treatment

\section{In vitro evaluation of plant extracts against the pathogen}

Different parts of nine plant species viz., onion bulb, garlic clove and leaves of lantana, marigold, datura, tulasi, eupatorium, parthenium and neem were used in this study (Table 2). The extract was obtained by crushing the tissues in distilled water at 1:1 w/v proportion.

The extract was filtered through double layered muslin cloth and later through Whatman No. 1 filter paper to get a clear filtrate. This filtrate was used as a stock solution for the study. The plant extracts were tested at 3 concentrations (5, 10 and 15\%) on potato dextrose agar medium. Poison food technique was followed to evaluate the antifungal activity of the plant extracts as mentioned earlier. Observations were recorded at five days after inoculation. Radial growth of the fungus was measured and per cent inhibition of mycelial growth was calculated using the formula given by Vincent (1947) as mentioned above. 
In vitro evaluation of bioagents against the pathogen

In vitro evaluation of four bioagents (Table 3) against $D$. oryzae was carried out using dual culture technique. Mycelial disc of the test fungus was inoculated at one end of the Petri plate and antagonistic fungus at the opposite end. In case of bacterial antagonist two mycelial disc of the pathogen were inoculated at the periphery of the Petri Plate and bacterial antagonist was streaked in the center of the same plate. Four replications were maintained for each treatment. The plates were incubated at $28^{\circ} \mathrm{C}$. The radial growth of the pathogen was measured. Zone of inhibition was recorded by measuring the clear distance between the margin of the test fungus and antagonistic organism. The per cent inhibition of growth of the pathogen was calculated by using the formula suggested by Vincent (1947). Analysis of the experimental data was done by using completely randomised design (CRD) for the laboratory studies as suggested by Panse and Sukathme (1985).

\section{Results and Discussion}

\section{In vitro evaluation of fungicide molecules}

Among the different fungicides tested, propiconazole $(25 \%$ EC) was significantly superior over the other fungicides. However it was on par with hexaconazole ( $5 \%$ SC), where both the fungicides recorded $100 \%$ mycelial growth inhibition at 100, 150, 200 and 250 ppm concentrations. Also that propiconazole (25\% EC) recorded $72.07 \%$ average mycelial growth inhibition which was on par with hexaconazole (5\% SC) $(72.95 \%)$ at $50 \mathrm{ppm}$ concentration. The results of present investigation are in conformity with the findings of Gupta et al., (2013) wherein they reported that propiconazole (25\% EC) was most effective in inhibiting the mycelial growth of $B$. oryzae with per cent inhibition of
$97.89,92.14,91.92,91.90$ and $90.87 \%$ at 250 , 200, 150, 100 and $50 \mathrm{ppm}$ concentrations, respectively (Table 1). Minimum per cent inhibition of $(29.65,32.87$ and $38.84 \%)$ mycelial growth was recorded in kresoxim methyl (44.3\% SC) at 150, 200 and $250 \mathrm{ppm}$ respectively, hence propiconazole (25\% EC) and hexaconazole (5\% SC) is found to be effective over the other chemicals.

\section{In vitro evaluation of plant extracts against the pathogen}

All the nine plant extracts tested suppressed the mycelial growth of the pathogen. The mycelial growth was reduced by $100 \%$ by garlic clove extract at all the 3 concentrations. The results are in accordance with Ahmed et al., (2002) and Ahmed et al., (2011), where the results obtained by Ahmed et al., (2012) reported $91.7 \%$ average mycelial growth inhibition of $B$. oryzae by garlic clove extract proving to be effective against the pathogen. This was followed by the marigold leaf extract which recorded 82.24, 85.55 and $88.16 \%$ mycelial growth inhibition at 5, 10 and 15 per cent concentration, respectively. Least per cent growth inhibition of 2.36, 5.71 and $10.0 \%$ was exhibited by eupatorium leaf extract followed by lantana leaf extract 4.73, 7.10 and $16.56 \%$ growth inhibition at 5,10 and 15 per cent concentration, respectively. Similar results on marigold leaf extract were reported by Islam et al., (2015) on Bipolaris sorokiniana with 73.74 per cent inhibition of mycelial growth at 10 per cent concentration (Table 2).

\section{In vitro evaluation of bioagents against the pathogen}

Antagonistic activities of four bio-agents viz., Trichoderma viride, T. harzianum, Pseudomonas fluorescens and Bacillus subtilis were evaluated against Bipolaris oryzae. The results are presented in Table 3. 
Table.1 In vitro evaluation of fungicides against growth of $B$. oryzae

\begin{tabular}{|c|c|c|c|c|c|c|c|}
\hline \multirow[t]{3}{*}{ Sl. No. } & \multirow[t]{3}{*}{ Treatments } & \multicolumn{5}{|c|}{ Per cent inhibition } & \multirow[t]{3}{*}{ Mean } \\
\hline & & \multicolumn{5}{|c|}{ Concentration (ppm) } & \\
\hline & & \multicolumn{2}{|r|}{100} & 150 & 200 & 250 & \\
\hline 1 & Tricyclozole (75\% WP) & $\begin{array}{c}30.92 \\
(33.78)\end{array}$ & $\begin{array}{c}32.83 \\
(34.95)\end{array}$ & $\begin{array}{c}35.30 \\
(36.45)\end{array}$ & $\begin{array}{c}38.57 \\
(38.39)\end{array}$ & $\begin{array}{c}42.13 \\
(40.47)\end{array}$ & $\begin{array}{c}39.95 \\
(35.06)\end{array}$ \\
\hline 2 & Benomyl (50\% WP) & $\begin{array}{c}38.14 \\
(38.13)\end{array}$ & $\begin{array}{c}40.78 \\
(39.68)\end{array}$ & $\begin{array}{c}44.78 \\
(42.00)\end{array}$ & $\begin{array}{c}48.13 \\
(43.92)\end{array}$ & $\begin{array}{c}49.11 \\
(44.49)\end{array}$ & $\begin{array}{c}44.18 \\
(39.94)\end{array}$ \\
\hline 3 & Carbendazium (50\% WP) & $\begin{array}{c}35.31 \\
(36.45)\end{array}$ & $\begin{array}{c}38.22 \\
(38.18)\end{array}$ & $\begin{array}{c}42.08 \\
(40.44)\end{array}$ & $\begin{array}{c}46.74 \\
(43.12)\end{array}$ & $\begin{array}{c}49.84 \\
(44.90)\end{array}$ & $\begin{array}{c}42.43 \\
(38.36)\end{array}$ \\
\hline 4 & Mancozeb (75\% WP) & $\begin{array}{c}51.09 \\
(45.62)\end{array}$ & $\begin{array}{c}57.46 \\
(49.28)\end{array}$ & $\begin{array}{c}59.67 \\
(50.57)\end{array}$ & $\begin{array}{c}65.28 \\
(53.89)\end{array}$ & $\begin{array}{c}70.32 \\
(56.98)\end{array}$ & $\begin{array}{c}60.76 \\
(48.49)\end{array}$ \\
\hline 5 & Propineb (70\% WP) & $\begin{array}{c}42.48 \\
(40.67)\end{array}$ & $\begin{array}{c}46.18 \\
(42.80)\end{array}$ & $\begin{array}{c}48.93 \\
(44.38)\end{array}$ & $\begin{array}{c}52.98 \\
(46.70)\end{array}$ & $\begin{array}{c}54.85 \\
(47.78)\end{array}$ & $\begin{array}{c}49.10 \\
(42.62)\end{array}$ \\
\hline$\overline{6}$ & Tebuconazole (25.9\% EC) & $\begin{array}{c}58.06 \\
(49.63)\end{array}$ & $\begin{array}{c}58.39 \\
(49.82)\end{array}$ & $\begin{array}{c}67.02 \\
(54.94)\end{array}$ & $\begin{array}{c}74.73 \\
(59.82)\end{array}$ & $\begin{array}{c}75.48 \\
(60.31)\end{array}$ & $\begin{array}{c}66.70 \\
(51.46)\end{array}$ \\
\hline 7 & Propiconazole (25\% EC) & $\begin{array}{c}72.05 \\
(58.08)\end{array}$ & $\begin{array}{c}100.00 \\
(89.99)^{*}\end{array}$ & $\begin{array}{c}100.00 \\
(89.99)\end{array}$ & $\begin{array}{c}100.00 \\
(89.99)\end{array}$ & $\begin{array}{l}100.00 \\
(89.99)\end{array}$ & $\begin{array}{c}94.42 \\
(79.35)\end{array}$ \\
\hline 8 & Hexaconazole (5\% SC) & $\begin{array}{c}72.95 \\
(58.65)\end{array}$ & $\begin{array}{c}74.23 \\
(59.48)\end{array}$ & $\begin{array}{r}100.00 \\
(89.99)\end{array}$ & $\begin{array}{l}100.00 \\
(89.99)\end{array}$ & $\begin{array}{l}100.00 \\
(89.99)\end{array}$ & $\begin{array}{c}89.36 \\
(69.38)\end{array}$ \\
\hline 9 & Kresoxim methyl (44.3\% SC) & $\begin{array}{c}22.60 \\
(28.35)\end{array}$ & $\begin{array}{c}25.58 \\
(30.38)\end{array}$ & $\begin{array}{c}29.65 \\
(32.99)\end{array}$ & $\begin{array}{c}32.87 \\
(34.98)\end{array}$ & $\begin{array}{c}38.84 \\
(38.54)\end{array}$ & $\begin{array}{c}29.90 \\
(30.58)\end{array}$ \\
\hline \multirow[t]{5}{*}{10} & Azoxystrobin (23\% SC) & $\begin{array}{c}34.48 \\
(35.96)\end{array}$ & $\begin{array}{c}38.88 \\
(38.57)\end{array}$ & $\begin{array}{c}40.35 \\
(39.43)\end{array}$ & $\begin{array}{c}42.42 \\
(40.63)\end{array}$ & $\begin{array}{c}46.49 \\
(42.98)\end{array}$ & $\begin{array}{c}40.52 \\
(37.99)\end{array}$ \\
\hline & & Fungicides (F) & \multicolumn{2}{|c|}{ Concentration $(\mathrm{C})$} & \multicolumn{2}{|c|}{ F X C } & \\
\hline & $\operatorname{SEm}( \pm)$ & \multicolumn{2}{|l|}{0.18} & & \multicolumn{2}{|r|}{0.53} & \\
\hline & CD@1\% & 0.31 & & & \multicolumn{2}{|r|}{1.05} & \\
\hline & CV\% & \multicolumn{5}{|c|}{0.87} & \\
\hline
\end{tabular}

*Figures in parenthesis are arcsine transformed values 
Table.2 Effect of different concentrations plant extracts against growth of B. oryzae under in vitro conditions

\begin{tabular}{|c|c|c|c|c|c|}
\hline \multirow[t]{3}{*}{ Sl. No. } & \multirow[t]{3}{*}{ Treatments } & \multirow{2}{*}{\multicolumn{3}{|c|}{$\begin{array}{l}\text { Per cent growth inhibition } \\
\text { Concentrations }(\%)\end{array}$}} & \multirow[t]{3}{*}{ Mean } \\
\hline & & & & & \\
\hline & & 5 & 10 & 15 & \\
\hline 1 & Onion (Allium сера) & $\begin{array}{c}76.33 \\
(60.87)\end{array}$ & $\begin{array}{c}76.52 \\
(60.88)\end{array}$ & $\begin{array}{c}78.30 \\
(62.17)\end{array}$ & $\begin{array}{c}76.95 \\
(61.37)\end{array}$ \\
\hline 2 & Garlic (Allium sativum) & $\begin{array}{c}100.0 \\
(90.00)\end{array}$ & $\begin{array}{c}100.0 \\
(90.00)\end{array}$ & $\begin{array}{c}100.0 \\
(90.00)\end{array}$ & $\begin{array}{l}100.00 \\
(90.00)\end{array}$ \\
\hline 3 & Lantana (Lantana camara) & $\begin{array}{c}04.73 \\
(12.52)\end{array}$ & $\begin{array}{c}07.10 \\
(15.46)\end{array}$ & $\begin{array}{c}16.56 \\
(23.82)\end{array}$ & $\begin{array}{c}9.37 \\
(17.34)\end{array}$ \\
\hline 4 & Marigold (Tegeteserecta) & $\begin{array}{c}82.29 \\
(65.32)\end{array}$ & $\begin{array}{c}85.55 \\
(69.80)\end{array}$ & $\begin{array}{c}88.16 \\
(69.75)\end{array}$ & $\begin{array}{c}86.23 \\
(68.38)\end{array}$ \\
\hline 5 & Dathura (Daturastramonium) & $\begin{array}{c}23.07 \\
(28.71)\end{array}$ & $\begin{array}{c}33.39 \\
(35.20)\end{array}$ & $\begin{array}{c}35.50 \\
(36.51)\end{array}$ & $\begin{array}{c}30.57 \\
(33.51)\end{array}$ \\
\hline 6 & Tulasi (Ocimumsantum) & $\begin{array}{c}70.41 \\
(57.19)\end{array}$ & $\begin{array}{c}74.55 \\
(59.99)\end{array}$ & $\begin{array}{c}74.55 \\
(59.91)\end{array}$ & $\begin{array}{c}73.45 \\
(58.81)\end{array}$ \\
\hline 7 & Eupatorium (Eupatorium rugosum) & $\begin{array}{l}02.36 \\
(9.07)\end{array}$ & $\begin{array}{c}05.71 \\
(13.65)\end{array}$ & $\begin{array}{c}10.0 \\
(18.49)\end{array}$ & $\begin{array}{c}6.04 \\
(13.70)\end{array}$ \\
\hline 8 & Parthenium (Partheniumhisteroporus) & $\begin{array}{c}70.41 \\
(57.30)\end{array}$ & $\begin{array}{c}73.30 \\
(58.96)\end{array}$ & $\begin{array}{c}79.30 \\
(59.80)\end{array}$ & $\begin{array}{c}72.98 \\
(58.81)\end{array}$ \\
\hline 9 & Neem (Azadirachtaindica) & $\begin{array}{c}73.96 \\
(58.97)\end{array}$ & $\begin{array}{c}75.93 \\
(60.33)\end{array}$ & $\begin{array}{c}78.69 \\
(62.19)\end{array}$ & $\begin{array}{c}75.72 \\
(60.32)\end{array}$ \\
\hline & & $\begin{array}{r}\text { Plant ext } \\
(\mathbf{P})\end{array}$ & CoI & $\begin{array}{l}\text { ntrations } \\
\text { (C) }\end{array}$ & P X C \\
\hline & $\operatorname{Sem}( \pm)$ & 0.11 & & 0.12 & 0.48 \\
\hline & CD@1\% & 0.24 & & 0.43 & 0.76 \\
\hline & $\mathrm{CV}(\%)$ & & & & \\
\hline
\end{tabular}

*Figures in parenthesis are arcsine transformed values

Table.3 In vitro evaluation of different bioagents against B. oryzae

\begin{tabular}{|c|c|c|c|}
\hline Sl. No. & Bioagents & $\begin{array}{l}\text { Mean radial } \\
\text { growth }(\mathrm{mm})\end{array}$ & Per cent growth inhibition \\
\hline 1 & Trichoderma viride & 32.33 & $48.49(44.13)$ \\
\hline 2 & Trichoderma harzianum & 35.33 & $40.76(39.67)$ \\
\hline 3 & Pseudomonas fluorescens & 43.67 & $27.57(31.67)$ \\
\hline 4 & Bacillus subtilis & 47.83 & $17.77(24.92)$ \\
\hline \multirow[t]{4}{*}{5} & Control & 59.66 & \\
\hline & $\operatorname{Sem}( \pm)$ & 0.33 & 0.51 \\
\hline & CD@1\% & 1.06 & 1.65 \\
\hline & $\mathrm{CV}(\%)$ & 1.45 & 2.66 \\
\hline
\end{tabular}

*Figures in parenthesis are arcsine transformed values 
The results, obtained revealed maximum inhibition of mycelial growth by $T$. viride $(48.49 \%)$ win comparison with other bioagents. Whereas, $T$. harzianum and $P$. fluorescens recorded $40.76 \%$ and $27.57 \%$ inhibition, respectively. Least per cent inhibition of $17.77 \%$ mycelial growth was recorded by $B$. subtilis. The present studies are in conformity with the observations made by Abdel-Fattah et al., (2007), wherein they reported that $T$. harzianum had better antagonistic activity thereby suppressing $83.33 \%$ mycelial growth of B. oryzae. Khalili et al., (2012) also recorded Trichoderma isolates significantly inhibiting the mycelial growth of the pathogen (69\%) under in vitro by producing volatile and non-volatile metabolites.

\section{References}

Abdel-Fattah, G. M., Shabana, Y. M., Ismail, A. E. and Rashad, Y. M., 2007, Trichoderma harzianum: a biocontrol agent against Bipolaris oryzae. Mycopathol., 164: 81-89.

Ahmed, M. F., Khalequzzaman, K. M., Anam, M. K. and Islam, T. M., 2002, Effect of plant extracts against Bipolaris oryzae under Invitro. Pakistan J. Biol. Sci., 5(4): 442-445.

Ahmed, S. G., Garg, V. K., Pandith, A. K., Anwar, A. and Aijaz, S., 2011, Disease incidence of paddy seedlings in relation to environmental factors under temperature agronomic conditions of Kashmir valley. $J$. Res. Dev., 11:29-38.

Amadioha, A.C., 2002, Fungitoxic effects of extracts of Azadirachta indica against Cochliobolus miyabeanus causing brown spot disease of rice. Arch. Phytopath. Pl. Protec. 35: 37-42.

Bedi, K.S. and Gill, H.S., 1960, Losses caused by the brown leaf spot disease in the Punjab. Indian Phytopath., 13: 161-164.

Bisht, G.S. and Khulbe, R.D., 1995, In vitro efficacy of leaf extracts of certain indigenous medicinal plants against brown leaf spot pathogen of rice. Indian Phytopath., 48: 480-482.

Grover, R. K. and Moore, J. D., 1982, Toxicometric studies of fungicides against brown rot organism Sclerotinia fructicola and S. laxa.Phytopathol.,52:876-880.

Gupta, V., Shamas, N., Razad, V. K., Sharma, B. C., Sharma, R., Kaur, K., Singh, I., John, D. and Kumar, A., 2013, Foliar application of fungicides for the management of brown spot disease in rice (Oryza sativa L.) caused by Bipolaris oryzae. African J. Agric. Res., 8(25): 3503-3309.

Islam, S., Ali, A. and Sarker, I., 2015, Efficacy of medicinal plants against seed borne fungi of wheat seeds. Int. J. Nat. Soc. Sci., 2: 48-52.

Khalili, E., Sadravi, M., Nacimi, S. and Khosravi, V., 2012, Biological control of rice brown spot with native isolates of three Trichoderma species. Brazilian J. Microbiol., 43(1): 297-305.

Kumar, A., 2006, Evaluation of botanicals against major pathogens of rice. Indian Phytopath., 59: 509-511.

Panse, V. G. and Sukathme, P. V., 1985, Statistical method for Agricultural workers.ICAR Publications, pp. 145-155. New Delhi.

Sunder, S., Ramsingh and Dodan, D. S., 2010, Evaluation of fungicides, botanicals and non-conventional chemicals against brown spot of rice. Indian phytopath. 63(2): 192194.

Sunder, S., Singh, R., Dodan, D.S. and Mehla, D.S., 2005, Effect of different nitrogen levels on brown spot (Drechslera oryzae) of rice and its management through host resistance and fungicides. Pl. Dis. Res. 20: 111-114.

Vincent, J. M., 1947, Distribution of fungal hyphae in the presence of certain inhibition. Nature, 150:850.

\section{How to cite this article:}

Channakeshava, C. and Pankaja, N.S. 2018. In Vitro Evaluation of Fungicides, Plant Extracts and Biocontrol Agents against Brown Leaf Spot of Paddy. Int.J.Curr.Microbiol.App.Sci. 7(05): 127-132. doi: https://doi.org/10.20546/ijcmas.2018.705.016 